\title{
A Tribute to Franklin H. Epstein (1924-2008)
}

\section{Mayer Brezis}

Center for Clinical Quality and Safety, Hadassah Hebrew University Medical Center, Jerusalem, Israel

During my recent sabbatical at Harvard in 2008, I made a visit to my lifelong mentor, Professor Franklin Harold Epstein, at his office in the Renal Division of Beth Israel Deaconess Medical Center. Despite his age (84), he was as sharp and as cordial as he had always been for the last 3 decades I was fortunate to know him. We discussed the current US healthcare crisis, the challenges of the widespread intrusion of the industry into medicine and the ethics of professional care for those nearing the end of life. He gave me a reprint of one of his most recent papers: 'The Role of the Physician in the Preservation of Life' [Q J Med 2007;100:585-589]. As he had done so many times for me and for others, he carefully read and annotated a draft paper of mine (on conflicts of interests and public health) and thoughtfully referred me for further discussion to his friend, A. Relman at the Harvard Medical School.

I did not realize then that this would be the last time I would enjoy and benefit from Frank's extraordinary wisdom and generous thinking. A few months later, Frank Epstein died of metastatic disease: this was a sad departure of one of the giants in nephrology of the last century.

Franklin H. Epstein received his medical degree in 1947 from Yale University, where he became interested in the field of fluid and electrolyte metabolism, inspired by Dr. John Peters, whom he would succeed as Chief of the

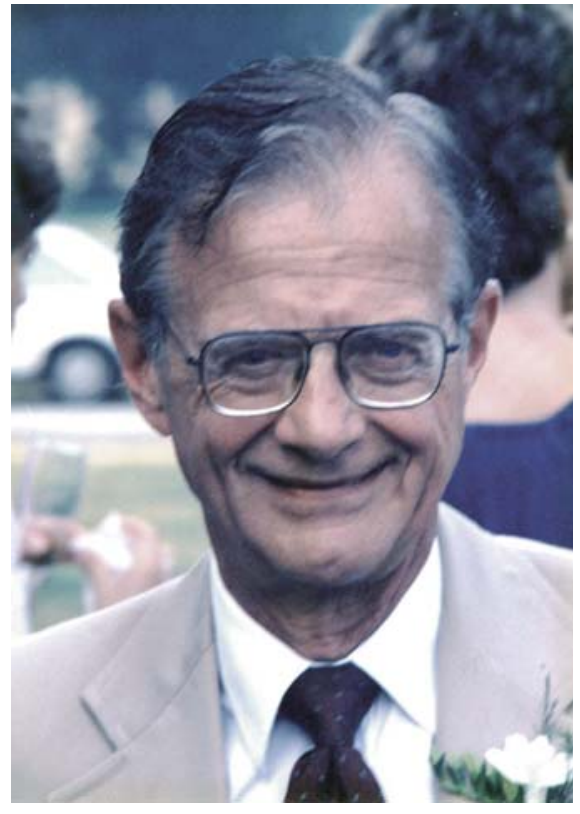

Division of Metabolism. In 1972, he moved to Boston and soon became Professor at Harvard, Chairman of Medicine and Chief of Nephrology at Beth Israel Hospital. He became widely admired for his innovative research and his incisive teaching, for his deeply sensitive and profes-

\section{KARGER}

Fax +4161306 1234 E-Mail karger@karger.ch www.karger.com
(C) 2010 S. Karger AG, Basel

$1660-2110 / 10 / 1144-0309 \$ 26.00 / 0$

Accessible online at:

www.karger.com/nec
Prof. Mayer Brezis, MD, MPH

Center for Clinical Quality and Safety

Hadassah Hebrew University Medical Center

PO Box 12000, Jerusalem 91120 (Israel)

Tel. +972 2677 7592, Fax +972 2643 9730, E-Mail brezis@vms.huji.ac.il 
sional approach to patients and for his outstanding charismatic leadership. He would spend his summer vacations in Maine, experimenting on fish at the Mount Desert Island Biologic Laboratory, doing a series of brilliant studies that would lead to novel insights into the role of the Na-K-ATPase in ion transport.

I met Frank for the first time during his visit to Israel in 1980, after he had spent a sabbatical at Oxford. He presented fascinating work on hypoxia of the renal medulla that he was undertaking with Brian Ross and Robert Balaban [Am J Physiol 1982;243:F356-F363]. Having been accepted as fellow in his Renal Division, I expressed to Frank my interest to work in this area. Instead, when I arrived in Boston, Frank asked me to work with the renal pathologist Seymour Rosen on a peculiar type of tubular damage noted during the isolated perfusion of rat kidneys. I remember Frank's supportive patience with my unsuccessful attempts during 6 months to elucidate the enigma: too much pressure in a highly competitive research atmosphere can lead to falsification and fabrication by young investigators! I will never forget Frank's visits to the laboratory where I worked, heralded by his marvelous whistling of melodies of classical music, his focused questions, his amiable humor, always leaving me with another reference to read or another novel way of thinking about a problem. He never gave up hope that my work would be fruitful, not even when, one evening, he silently looked at the mess I had made in the lab in the process of setting up an isolated kidney perfused with a medium enriched with red blood cells; this turned out to be a pivotal experiment as only then did we realize that the injury seen in the isolated perfused kidney represented a selective vulnerability of the thick ascending limbs to medullary hypoxia [J Clin Invest 1984;73:182-190]. This realization rapidly led to the understanding of a crucial role of active transport work in medullary hypoxic injury [Science 1984;224:66-68], to the development of novel models of acute renal failure [J Clin Invest 1988;82: 401-412] and to proposing a potential role for medullary hypoxia in renal pathophysiology [N Engl J Med 1995; 332:647-655].

I recall from my personal experience that Frank's presence was always conducive to scientific inquiry in the best tradition of searching for the truth in order to better understand the human body and all the time never losing sight of his core objective, which was to help patients. To this end he used the most modern tools to query and rigorously assess and review the most recent findings and theories. Another notable trait I observed in Frank was his generous sharing of resources with others; he was al- ways ready to help anyone who came to him for advice and was always happy to lend out equipment or provide support in any way he could. It was quite remarkable to see how this attitude would be emulated by those who surrounded Frank (for instance, whenever I went to other labs seeking assistance) - a practice unfortunately not always observed in other academic institutions I have visited over the years.

Frank was responsible for nearly 400 publications and was a distinguished editor of Harrison's Principles of Internal Medicine, of the Journal of Clinical Investigation, of the Yearbook of Medicine, of the Quarterly Journal of Medicine, and of the New England Journal of Medicine. His scientific contributions received many honors, such as the John P. Peters Award of the American Society of Nephrology, the Bywaters Award of the International Society of Nephrology, the Edward N. Gibbs Award of the New York Academy of Medicine and the David Hume Award of the National Kidney Foundation.

Frank also had a remarkably humanistic clinical approach. He had an outstanding way to combine his encyclopedic knowledge with a careful tracing of the patient's history and findings to construct a pathophysiological basis to sharp diagnostic and therapeutic solutions - always with a deeply sensitive caring for human dignity. I remember during rounds with Frank his soft knock on the door of the patient's room, his joyful greeting, his thoughtful listening and his gentle touching during the examination. He used the best intelligent efforts to serve the patient, in the best tradition of the caring physician - what we now call professionalism. He wrote in one of his last papers [Q J Med 2007;100:585-589]:

'Too often, in our hospital routine, the prescription of 'Comfort Care Only' means that we don't bother seeing the patient on rounds. After all, there are no lab results to discuss. But it is precisely these patients who need human touch the most. Nurses know that - doctors rarely do. Touching is important, especially for those to whom we can offer little else. Dickinson Richards, the great New York chest physician, who headed the Columbia service at Bellevue Hospital, said that the great virtue of the stethoscope was that it brought the doctor very close to the patient. Even in their final hours, semi-conscious, patients know when they are being abandoned or attended by a humane and unhurried doctor.'

One of the dearest gifts I was fortunate to receive from Frank was the enthusiasm to combine science and humanism, and the fervor to strive to give the best to my own patients, students, residents and colleagues. I'm deeply grateful to Frank and his departure is an immeasurable personal loss to me, as it is for many others who have known him. 